\title{
EFFECT OF COST ON THE QUALITY OF MBA PROGRAMMES IN UGANDAN UNIVERSITIES
}

\author{
Wilson Muyinda Mande - Nkumba University
}

\begin{abstract}
The current study set out to assess the effect of cost on the quality of Master of Business Administration [MBA] programmes in Ugandan Universities using a hypothesised model. The research was carried out in six universities of Makerere, the Islamic University in Uganda, Nkumba, Ndejje, Makerere Business School and Uganda Martyrs University. A purposely designed questionnaire was distributed to 100 students in the six 14 universities. The findings showed that: one, there were significant differences $[F(5,44)$ $=3.606, P<0.01]$ among the universities as far as the cost of the MBA was concerned; two, 19\% of students' academic work was influenced by cost; three, the academic work alone explained $32 \%$ of the quality of the MBA; four, in order to prove whether quality of the MBA is a function of cost or $q=f(c)$, a path analysis was done. The hypothesised model revealed that $68 \%$ of the quality of the MBA was dependent on cost. So a quality $M B A$ requires substantial financial input. Given the above resultant statistic, this study recommended that all universities in Uganda carry out appropriate costing of all academic programmes in order to have quality. The second recommendation was student loan scheme be introduced by government to enable students with financial hardship to borrow money and complete their courses.
\end{abstract}

\section{Background}

This study set out to examine the effect of cost on the quality of the Master of Business Administration (MBA) programmes in Ugandan universities. The research focused on six universities of Makerere University Kampala (MUK), the Islamic University in Uganda (IUIU), Nkumba University (NU) Ndejje University (NdU) Makerere University Business School (MUBS) and Uganda Martyrs University (UMU). The current study is premised on the fact that although MBA is a popular academic programme and many students enrol on it, not all students who join it finish on time or finish at all. Many who do not finish on time often cite failure to raise the required fees as the main cause of their attrition. Yet commentators like Bickerstaffe (2004) intimated that quality MBA are expensive, implying that the more spent, the cost the higher the quality of an MBA.

The MBA appeared in the USA at the start of the 20th century, developing from the accounting and book-keeping courses. It was introduced as the USA lost its frontier image and began to industrialise. It was modelled on the standard American two-year postgraduate academic programme and most students enrolled straight after taking a first degree. This model won rapid acceptance and spread quickly. Half a century later, MBA programmes were attacked for alleged lack of academic rigour and poor relevance to business issues. Two damning reports appeared in 1959, condemning American graduate management education as little more than vocational colleges filled with second-rate students taught by second-rate professors who did not understand their fields, did little research and were out of touch with business. Business schools responded rapidly, raising both their admissions and teaching standards and establishing the now well-known emphasis on academic research. The overall effect was the creation of the classic Ameri- 
can MBA model: a first year of required core courses to provide grounding in the basics of management and a second year of electives to allow specialisation or deeper study. This is the type of MBA followed in most of Ugandan universities.

The early 1990s saw further changes to MBA curricula and programme design, particularly in North America. These were a reaction to criticism of the degree from business and industry, to press and media reports echoing those criticisms, and to some extent to the growth of media rankings of MBA programmes and business schools. This time the criticism focused on a supposed lack of relevance to modern business. The MBA was said to be too academic, too theoretical and divorced from real-life business practice. MBA graduates were criticised for adopting an analytical and quantitative approach to business issues when companies needed managers with more diffuse skills, such as leadership. Faculty members were said to lack business experience and to be more interested in research than in providing business solutions. Interestingly enough in Uganda most popular opinion is that the MBA should be academic and participants on the course should be recruited on the basis of their earlier academic achievements and not leadership or work experience.

Other factors were also driving change. Recruitment of MBA graduates by management consultants and financial services was in decline so there was a need to develop other job markets. The globalisation of business was making many of the MBA programmes look increasingly parochial. The changes that business schools made in their MBA programmes involved three main elements: (i) the introduction of training in soft skills such as leadership, ethics and interpersonal skills; (ii) an increased stress on internationalism as a pervasive issue in all MBA courses; and (iii) an acknowledgement that MBA programmes should be practical and integrate the various management functions.

Now, in the 21 st century, there are signs that the MBA is undergoing change yet again with an increasing emphasis on leadership, entrepreneurship, and business ethics. These issues are given tremendous emphasis in Ugandan universities may be as a response to dynamics in the business and public sectors.

\section{Problem statement}

There is a need to empirically prove whether cost is an overriding determinant of the quality of an MBA programme in Ugandan universities. Bickerstaffe (2004) has associated cost with quality of the MBA. He cited the Kellogg MBA whose tuition was $\$ 34,000$ per year in 2004. Other expensive MBAs include Harvard whose tuition is $\$ 46,150$ and the London MBA which costs $£ 19,250$ a year. These are said to be quality MBAs. In Uganda MBAs are popular. In spite of the fact that the MBA is a well sought after postgraduate course, not all students who enrol on it complete it on time. Consequently there are those who have enrolled on it but failed to complete. Others have had to postpone the course for some time. Most of the students who have fallen in this category have cited the cost of the MBA as the major cause of their attrition.

It appears the cost of the MBA is higher than a significant number of students can afford. Yet some commentators like Hansen (2009) have intimated that not all MBAs are the same in quality. He has also stated that a good quality MBA is associated with the amount of tuition students pay. If the money is well used, all the resources needed for 
the MBA will be procured. So the higher the cost the better the quality of the MBA.

It is presumed that the MBA is normally a course for working people probably at the management level and are therefore able to meet the concomitant costs. The Prime Minister of Uganda addressing a graduation assembly at Makerere University in April 2006 intimated that the cost of education in Ugandan universities was very low. Does this mean that the cost of the MBA is not high enough? Does it also imply that the MBA quality is not high? There are some few MBA students who have attempted to revert to postgraduate diplomas in business administration instead of the MBA in order to cut costs but graduate with some postgraduate qualification. Some significant minority $(15 \%)$ of the students have just given up the MBA altogether. So it seems that cost affects quality of the MBA programme in Ugandan universities. These issues made the current study a matter of course in order to establish empirically the effect of the cost on the quality of the MBA.

\section{Purpose and objectives}

The purpose of the current study was to examine the effect of cost on quality of the MBA programmes in Ugandan universities.

The specific objectives are:

(i) To determine whether there was a significant variation in the costs incurred by MBA students at the different Ugandan universities.

(ii) To analyse the relationship between cost of MBA and the fulfilment of academic work requirements.

(iii) To establish the relationship between academic work and quality of the MBA in Ugandan universities.

(iv) To assess the effect of cost on the quality of the MBA in Ugandan universities.

\section{Hypotheses:}

Hypothesis 1 Costs incurred by the MBA students $H_{0}^{1}$ There is no significant variation in the cost of the MBA offered at different universities in Uganda. $H_{A}^{1}$ There is a significant variation in the cost of the MBA offered at different universities in Uganda Hypothesis 2. Relationship between costs of the MBA and academic work $\boldsymbol{H}_{\mathrm{o}}^{2}$ There are no significant relationship between costs of the MBA and the fulfilment of academic work requirements. $H_{A}^{2}$ There are a significant relationship between costs of the MBA and the fulfilment of academic work requirements. Hypothesis 3 Relationship between academic work and quality of the MBA $H_{0}^{3}$ There are no significant relationship between academic work and the quality of the MBA There are a significant relationship between academic work MBA and the quality of the MBA. Hypothesis 4 Relationship between the costs of MBA and quality of the MBA $H_{o}^{4}$ There is no significant relationship between the cost and the quality of the MBA. $H_{A}^{4}$ There is a significant relationship between the cost and the quality of the MBA.

\section{Literature Review}

Literature was reviewed under the following sections: survey of available literature on the topic, context of literature, admission to the MBA, benefits of the MBA, leadership learnt through the MBA, student satisfaction with the methods of the MBA, gender 
based perspective on the MBA, the cost of the MBA, the quality of the MBA and cost and quality of the MBA considered together.

\section{Available literature on the MBA in Uganda}

There is apparently no literature on the effect of cost on the quality of the MBA in Ugandan universities. What is available does not address the concerns of the current study directly. For instance Epelu-Opio (2002) examined the education reform at Makerere University. On funding he noted that the money from the government had not only reduced but disbursements had been irregular and some items had been suspended. In response to the cuts in funding, Makerere transformed from fully government funded to partially private institution. What Epelu-Opio says is pertinent but does not concern himself with the interplay between cost and quality of the MBA and how that constrains students' academic work. Mayanja (2002) focused on graduate employment in Uganda. Although this is important, his paper did not directly address the issues of MBA's cost and quality in Ugandan universities.

Hayward (2004) writes about higher education support and funding. On Uganda, he notes the implications of the "Strategic Plan for Higher Education 2003-2015". The implied goals include: (i) Greater budget support from government and other stakeholders to rehabilitate, construct, and improve facilities so that tertiary education can grow from approximately 80,000 to 126,396 students by 2015 ; (ii) Funding to expand ICT equipment, capacity, curriculum and staffing; (iii) Establishment of a salary package based on staff training; (iv) Set up a research fund at each institution that constitutes 3-5\% of the wage bill; (v) Provide quality higher education accessible to all qualified Ugandans by 2015; (vi) Improve access for students from poor families; and (vii) Improve gender equity with a target of $51 \%$ women by 2015 . As rightly pointed out by Hayward, all the above goals require funding of government, students, parents, donors, business, and public. This clearly means that students have to play a bigger role in the funding of the MBA.

Appleton (2001) carried out research on education, incomes and poverty in Uganda in the 1990s. He concluded that there was growth in living standards and poverty reduction among the more educated households. He also investigated the direct productivity effects of education on earnings from each income source and found that they had increased overtime. Appleton's study has relevance to the current study but does not include perspective of the key stakeholder on education, that is, the students. Kajubi (2001) addressed the issue of coping with the challenges of higher education in the $21 \mathrm{st}$ century. He reasons that the challenges are many and they include the economic ones. However, he does not go far enough to compare the interplay between cost and quality of the MBA programmes and the constraints this exerts on students pursuing the same.

Court (1999) examined the financing of higher education in Africa with particular reference to Makerere University. He contended that there was a quiet revolution at Makerere as enrolment had expanded and private sponsorship introduced. All these meant a big departure from the tradition of Makerere thereby constituting a revolution. This is an important study but does not address the issue of the cost of the MBA specifically. It is evident from the literature cited above that the available literature does not address the theme of the current study. 


\section{Context of the literature on the MBA}

There is a preponderant number of publications about the MBA programme. The writings focus most on the MBA in the contexts of Europe, Australia, the USA and Asia (Arbaugh, 2000; Blair, 1998; Brown, 2000; Fox, 2008; Kaiza, 2001; Kleiman and Kass, 2007; James, 2008; Mattis , 2008; Harris et al; Cohen and Miaoulis, 1978; Sinclair, 1997; Golen, 1989; Deconink and Steiner, 1999; Castleberry, 2007; Thursfield, 2008; Maxwell, 1986; Miller et al, 2007; Thompson, 2002; Bowman, 2007; Duncan, 1986; Elkin, 1991; Viljoen et al, 1990; Sims, et al, 1994; Dacko, 2001; Tonn and Milledge 2002; Simpson et al, 2005; Gabriel, 2005; Naude et al, 1997; Hay and Hodgkinson, 2008; Polvnick, 1979). Although these studies are very good in articulating the theories that underpin the MBA, they do not address Ugandan setting, hence leaving a gap that the current study seeks to fill.

\section{Admission to the MBA}

There are studies that have focused on the admissions to the MBA. For instance Elkin (1991) explains the decision-making process for admitting students to the executive MBA programmes. The executive MBA is slightly different from the traditional MBA course. That difference calls for different admission criteria. In Ugandan universities, the executive MBA programmes are just getting established in Uganda. Viljoen et al (1990) investigated the students' perspectives on entry levels. Of course every university has its own admission criteria to the MBA. What the above authors studied was good except that they did not examine the role of cost in admission. Hansen (2009) implored that "you want a graduate programme with tough admissions standards; it is better to be among the select few than with a larger group that may end up lowering the quality of your graduate education... also look at base requirements for admission, which usually include undergraduate grade-point-average and standardized test scores." There are business schools that teach little but pride in admitting students with higher points. The above studies did not answer questions of the current study.

\section{Benefits of the MBA}

The theme of benefits of the MBA is pursued by Simpson et al. (2005). These authors using a Canadian based survey of career benefits found that gender and age interact to influence perceptions about career. They also found that both men and women gained intrinsic benefits from the MBA. On the value of MBA, Thomas (1984) examined the value of the MBA in terms of the skills MBA graduates acquire and the needs of the employers. His study tried to analyse the benefits of the MBA for its recipients. James (2007) stated that for years, an MBA degree has been seen as a first-class ticket to the management fast track. Some spend $\$ 100,000$ or more to earn the degree, confident that it will propel their career into overdrive - and often that is not an unreasonable expectation. To many hiring managers, an MBA on the résumé is a sure sign that the candidate has long-term, corner-office potential. So the MBA has been regarded by many to be that type of degree which had wonderful benefits.

\section{Leadership learnt through the MBA}

In his study on whether the MBA programme encouraged the emergency of leadership qualities, Gabriel (2005) contended that the structure, ideology and ethos of the 
MBA programmes are fundamentally opposed to an education of leaders. He argued that MBAs teach students to be followers and not leaders. On her part Isabella (2005) found that some institutions had a methodology of using teams to teach about teams. Earlier on, in 2002, Tonn and Milledge had focused their study on team building in the MBA course. Fine studies but different in focus from the concerns of the current study. Hence the need for the current study.

\section{Student satisfaction with the methods of the MBA}

Arbaugh (2000a) researched on the virtual classroom characteristics and student satisfaction with the internet based MBA courses. Regarding the MBA programme and management education, Kleiman and Kass (2007) found that MBA programmes were criticised over their curricula which failed to enable students to acquire knowledge, skills and abilities in order for them to be competent in the business world. He proposed a stepby-step approach in guiding the implementation of a proactive mission-based approach. Buller et al (1995) examined a model for developing student skills and assessing MBA programme outcome through outdoor training. Thursfield (2008) studied an in-house MBA that was created explicitly to promote collective learning among managers in UK local authority. An experiential orientation to the MBA programme was studied by Nath (1975). Nath regarded this to be a management training laboratory. Similarly, Richards (1997) examined the aspect of developing cross-cultural management skills. Thompson studied the Chinese perspectives on the important aspects of an MBA teacher. Studies such as these give wonderful view on the MBA and are commendable. However, as far as focus and context are concerned they are different from the current study.

\section{Gender based perspective on the MBA}

Sinclair (1997) in her study noted that women prefer to be taught in ways that depart from the traditional MBA approaches. Good but her theme is not yet a concern in Ugandan MBA context.

\section{Cost and quality of the MBA}

Smith (2002) argued that in Asia, when it came to MBA programmes, cost and quality were kings. He examined what made a good MBA programme, as well as what schools in the region were doing to grab their share of students for Asia's top MBA schools. Smith pointed out that "many MBA programmes exist around the world, and attracting students has become a fiercely competitive marketing exercise. This is evident in the Asia Pacific, where universities are still finding their niche in the higher echelons of business education". Students joining the MBA in Asia look for (i) good value for money, (ii) international networking opportunities, (iii) international exposure, (iv) cost is a significant and attractive factor to consider, and (v) quality of some of the MBA programmes. Smith states that "the median fee for an MBA in Australia is US\$12,598 per year which is less than half the median of the most expensive US ones. Add on the cost of living, and the total comes to US\$23,518. This is more expensive than New Zealand, for which the total median is US\$19,012, as well as the UK". He gave a comparison of the cost of the MBA in Australia, New Zealand, UK, Canada, and USA. He did not provide comparative figures for the MBA programmes in Africa. For that matter, Smith's study leaves a gap that need to be filled hence the current study. 
Quality of the MBA

Seventeen items are presented by Hansen (2009) as the criteria for assessing the quality of the MBA. The items to consider are: accreditation of business School, admission standard, career assistance, costs, financial assistance to students, culture, degrees offered, faculty or staff, location, diversity of opportunities, physical facilities, academic focus, research, resources, size, state regulations and the surrounding community. These items will definitely vary from university to university. Hansen's advice goes for both students and business schools. Whereas some of items Hansen identifies are important for Ugandan setting, some of them do not weigh heavily as indicators of quality MBA.

The MBA is said to be falling short of what it is expected of. James (2008) outlines five "hard truths", which are: (1) the return on investment in the MBA is not what is used to be; (2) the training offered to MBA has become too theoretical to meet the needs;

20 (3) some of the people skills needed to be a manager today cannot be taught in a business school environment; (4) MBA programmes propagate management fads or myths; and (5) the pressure to succeed inside the MBA programmes has weakened safeguards against cheating. The relevance of some of these so-called hard truths needs to be investigated in the Ugandan universities.

\section{MBA and Entrepreneurship}

James (2007) observed that college drop-outs made successful entrepreneurs. He stated that; "Nobody would argue that it makes more sense to hire a college drop-out and former disk jockey like myself rather than a Harvard MBA. However, the high-tech world is full of college drop-outs that have made good. And among that group which includes [Bill] Gates, [Larry] Ellison, [Michael] Dell and [Steve] Jobs, I am the underachiever. If you look at what we hold in common, it's that we're all too fiercely entrepreneurial to have the patience for going to classes and getting certified. There are just some people who are driven to start a business, and those are the ones who aren't likely to spend time earning an MBA."

Even in Uganda some of the successful entrepreneurs did not have an MBA in the first place. Wavamunno (2000:41) a leading successful entrepreneur in Uganda states that "although I passed my examinations very well and was admitted to Mbarara High School, I decided not to go for further studies in order to have an early start in business". Such views even raise the question should someone do an "MBA in Entrepreneurship"?

All the literature above does not deal with the themes like the effect of cost on the quality of the MBA. This clearly reveals the gap which the current study seeks to fill.

\section{Methodology}

The current study employed basically three methods of data collection. These were: (1) interviews of 12 MBA students, two from each university. Through this method it was possible to obtain more and detailed information. (2) Review of secondary literature - helped to clarify concepts associated with the MBA. (3) Self administered questionnaire. The questionnaire had 79 items and 76 of these were on a five-point Likert scale: $1=$ strongly disagree, 2 = disagree, $3=$ neutral, $4=$ agree and $5=$ strongly agree. The questionnaires were distributed to 100 respondents. The questionnaire was the main method of data col- 
lection from MBA students at the universities of MUK (16 respondents); IUIU (16 respondents); NU (17 respondents); UMU (16 respondents); MUBS (19 respondents) and NdU (16 respondents). The respondents identified were suited to respond to the items on the questionnaire because they were the ones meeting the costs of the MBA, and experiencing the learning offered under the MBA. The sample of 100 was determined using Roscoe's (1975) rule of the thumb. He contended that any sample between 30 and 500 would sufficient to give credible results.

A path analysis was used to develop a predictive model regarding cost and quality of the MBA. The purpose was to establish a model which affirms that the quality of the MBA is always a function of the cost.

\section{Results and interpretation}

The four hypotheses were tested and the results of each are presented here below. The first hypothesis was tested using a one way ANOVA and the remaining three hypotheses were subjected to bivariate correlation and simple linear regression tests so as to determine the nature of the relationship between variables and to establish the contribution of each independent variable unto the dependent one. Then a path analysis was done.

\section{Hypothesis 1: The variation in the cost of MBA at Ugandan universities.}

The first null hypothesis [ $H_{0}^{1}$ ] stated that, "There is no significant variation in the cost of the MBA offered at different universities in Uganda". This hypothesis was tested using ANOVA which yielded the results are indicated in Table 1:

\section{Table 1. Difference in cost of MBA among Ugandan universities}

\section{MBA cost Sum of Squares df Mean Square F Between Groups 6.27951 .256

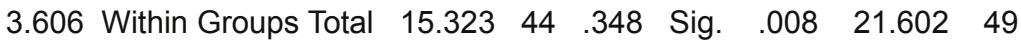

As the results in Table 1 indicate, there were significant differences in the cost of the MBA at the various Ugandan universities $[F(5,44)=3.606 . p<0.01]$. In order to determine exactly where the differences lay, a Gabriel post hoc test was executed. It revealed that there were significant differences on the following items: (i) whether the fees paid included money for accommodation, IUIU and NU differed $(1.74, p<0.01)$ and also NU and UMU charged differently $(1.49, \mathrm{p}<0.01)$. There were variations also regarding the MBA fees being inclusive of health fees. The following universities differed significantly: MUK and NU (1.49, p<0.01); MUK and MUBS (1.14, $<<0.05)$; MUK and $\operatorname{NdU}(1.25, \mathrm{p}<0.01)$; IUIU and NU (1.36, $\mathrm{p}<0.01)$ and IUIU and MUBS $(1.02, \mathrm{p}<0.05)$. On the whether the MBA fees included computer fees, two universities differed, that is MUK and NdU (1.31, $\mathrm{p}<0.05)$. So MBA costs in Uganda differ significantly.

In addition to the above differences in user fees charged by the universities, there were also clear differences in the tuition fees charged by each university. Some universities charge fees per semester. In the former case, a student is billed three times a year while in the latter; a student is billed twice a year. The frequency of billing is not a key issue but the total amount paid by end of academic year. This is well illustrated in Table 3: 
Table 2 tuition for the MBA in six Ugandan universities 2007-2008

\begin{tabular}{|c|c|c|c|}
\hline & University & $\begin{array}{l}\text { Tuition per semester } \\
\text { (in } \cup G X \text { ) }\end{array}$ & $\begin{array}{l}\text { Tuition for a whole } \\
\text { year (in UGX) }\end{array}$ \\
\hline & Makerere University (MUK) & $1,500,000 \times 2$ & $3,000,000$ \\
\hline & Islamic University in Uganda (IUIU) & $900,000 \times 3$ & $2,700,000$ \\
\hline & Nkumba University (NU) & $920,000 \times 3$ & $2,760,000$ \\
\hline & Uganda Martyrs University (UMU) & $\begin{array}{l}3,365,000 \times 2 \\
1,950,000 \times 2\end{array}$ & $\begin{array}{l}\text { 6,730,000 Fulltime } \\
2,900,000 \text { part time }\end{array}$ \\
\hline \multirow{2}{*}{22} & $\begin{array}{l}\text { Makerere University Business School } \\
\text { (MUBS) }\end{array}$ & $1,300,000 \times 2$ & $2,600,000$ \\
\hline & Ndejje University (NdU) & $1,900,000 \times 2$ & $3,800,000$ \\
\hline
\end{tabular}

[ $x 2$ and $x 3$ mean there are two semesters and three quotas respectively]

Given the results in Table 2 it is true to conclude that the null hypothesis was jettisoned and the alternate hypothesis $\left[H_{A}^{1}\right]$ "There is a significant variation in the cost of the MBA offered at different universities in Uganda" was supported instead. This implies that potential MBA students have to choose MBA schools rationally because universities do not charge the same amount of tuition. Some obviously charge more than others.

\section{Hypothesis 2: Relationship between MBA cost and students' academic work}

The second null hypothesis $\left[H_{0}^{2}\right]$ was "There are no significant relationship between costs of MBA and academic work." This hypothesis was first tested using Pearson's product moment correlation. The outcome of Pearson's correlation test indicated that there was a moderate positive significant relationship between cost of the MBA and academic work $[\mathrm{r}(100)=.447, \mathrm{p}<0.01]$. The more money one spends on study resources, the better academic work.

A simple linear regression test indicated that there was a linear relationship between cost and academic work of the MBA $[F(1,98)=24.425, p<0.01]$. This meant that when MBA students are able to meet the cost of the MBA, they would be able to carry out the academic work more effectively. This is because money helps to facilitate the learner.

The Adj. $\mathrm{R}^{2}$ from the model summary of the regression was .191 . This meant that the model explained only $19 \%$ to MBA students' academic work.

\begin{tabular}{|c|c|c|c|c|c|}
\hline \multirow{2}{*}{ Model } & \multicolumn{2}{|c|}{$\begin{array}{c}\text { Unstandardised } \\
\text { Coefficients }\end{array}$} & $\begin{array}{c}\text { Standardized Coef- } \\
\text { ficients }\end{array}$ & \multirow{2}{*}{$\mathrm{t}$} & Sig \\
\cline { 2 - 4 } & $\mathrm{B}$ & Std. Error & Beta & & \\
\hline 1 (Constant) & 1.196 & .470 & & .544 & .013 \\
MB A cost & .708 & .143 & .447 & 4.942 & .000 \\
\hline
\end{tabular}

Table 3 The effect of MBA costs on students' academic work

In view of the results $($ Beta $=.447, p<0.01]$ in Table 3 it means that cost is a factor to 
be given due attention as far as the costing of the MBA programme is concerned. The null hypothesis $\left[H_{A}^{2}\right]$ stated that; "there is no significant relationship between costs of the MBA and students' academic work". Each additional cost incurred on the MBA programme results into a significant $(\mathrm{p}<0.01)$ improvement in the students' academic work. In that way the null hypothesis was rejected and the alternative hypothesis $\left[H_{A}^{2}\right.$ ], "there are significant relationship between cost of the MBA and students academic work" supported.

On the cost of the MBA being affordable, most respondents as shown in pie chart in figure 1 intimated that it was not easily affordable.

Figure 1 a Pie chart on whether university fees are affordable

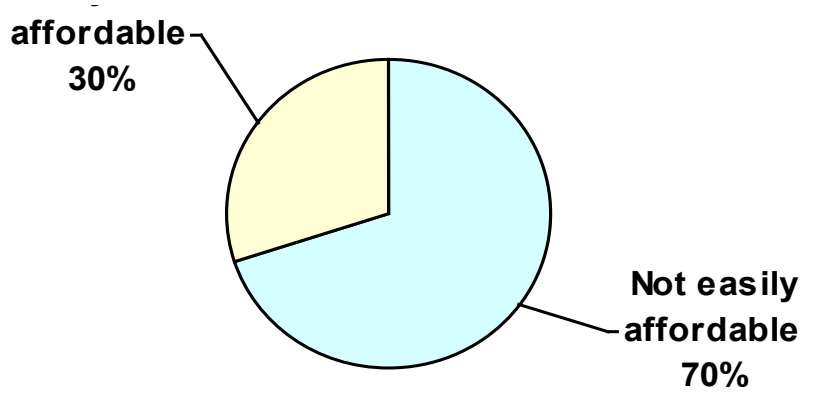

It is clear, $70 \%$ of respondents did not find the cost of the MBA affordable. In addition to that about $62 \%$ of the respondents showed that functional fees, that is, other expenses besides tuition were not easily affordable. Cost affected the academic work in the ways as given in Table 4 .

Table 4 academic work and expenses

\begin{tabular}{|l|l|l|}
\hline \multicolumn{2}{|l|}{ Academic activity and expense } & $\begin{array}{l}\% \text { of yes } \\
\text { responses }\end{array}$ \\
\hline 1 & $\begin{array}{l}\text { MBAs that require students to do field research and write dissertations } \\
\text { are very expensive and only achieved with some amount of financial } \\
\text { difficulty }\end{array}$ & 69 \\
\hline 2 & $\begin{array}{l}\text { MBA that require students to do industrial training are rather expensive } \\
\text { and only achieved with some amount of difficulty }\end{array}$ & 60 \\
\hline 3 & $\begin{array}{l}\text { Whether a student was able to buy at least one book in each subject } \\
\text { on module every semester }\end{array}$ & 42 \\
\hline
\end{tabular}

In view of the percentages in Table 4, it can be stated that a bigger proportion of MBA students in Ugandan universities experience financial difficulty in their course with studies. Those who complete their studies do so only with some amount of financial difficulty. Only about a quarter of the MBA pay their fees with ease. 


\section{Hypothesis 3: Relationship between academic work and quality of the MBA}

The relationship between academic work and the quality of the MBA was also examined because how much effort, time, and resources invested into the MBA academic work makes a difference in the quality of the MBA. It is presumed that those MBA students who have a sufficient number of lecturers, a well stocked library, and easy access to computers, well structured curriculum and the like will learn more and will therefore affect the quality of education they get from their MBA studies will be higher.

The third null hypothesis $\left[H_{0}^{3}\right]$ stated that "There is no significant relationship between academic work and the quality of the MBA". This hypothesis was first tested using 24 bivariate correlation. The results, $\mathrm{r}(100)=.570, \mathrm{p}<0.01$, indicated that there was a moderate positive relationship between academic work and the quality of the MBA. It was proved that the more academic work MBA students engage in, the better the quality of their MBA.

The hypothesis was also subjected to a simple linear regression. The regression of this test showed that the Adj. $\mathrm{R}^{2}$ was .319 which meant the model explained $32 \%$ of the quality to the MBA. This implied that academic work accounted for $32 \%$ of the variations in the perceived quality of the MBA programme holding other variables constant. The results also revealed that academic work and quality of the MBA had a linear relationship $[\mathrm{F}(1,20)=47.272, \mathrm{P}<0.01]$, the implication here is that any additional unit of the independent variable, will automatically lead to additional rate of the quality of the MBA.

Table 5 Contribution of the academic work and quality of the MBA

\begin{tabular}{|c|c|c|c|c|c|}
\hline \multirow{2}{*}{ Model } & \multicolumn{2}{|c|}{$\begin{array}{c}\text { Unstandardised Co- } \\
\text { efficients }\end{array}$} & $\begin{array}{c}\text { Standardized } \\
\text { Coefficients }\end{array}$ & \multirow{2}{*}{$\mathrm{t}$} & Sig \\
\cline { 2 - 4 } & $\mathrm{B}$ & Std. Error & Beta & & \\
\hline 1 (Constant) & 1.594 & .559 & & 2.851 & .005 \\
Academic work & 1.060 & .154 & .570 & 6.875 & .000 \\
\hline
\end{tabular}

From Table 5, it is seen that costs had a moderate positive significant contribution to the quality of the MBA $($ Beta $=.570, \mathrm{p}<0.01)$. In view of the above results it can be asserted

that null hypothesis $\left[H_{0}^{3}\right]$, “There is no significant relationship between academic work and the quality of the MBA" was rejected and the alternate hypothesis $\left[H_{A}^{3}\right]$ "There is a significant relationship between academic work and the quality of the MBA" supported instead.

\section{Hypothesis 4: The relationship between the cost and quality of the MBA}

It is important to examine the relationship between cost and quality of the MBA in Ugandan universities. Whereas cost refers to all the expenses MBA students incur in order to complete their studies successfully, the academic quality can be described as "a way of describing how well the learning opportunities available to students help them to achieve their award. It is about making sure that appropriate and effective teaching, 
support, assessment and learning opportunities are provided for them" (A brief guide... 2005). This definition of quality applies appropriately to the MBA studies.

So the fourth null hypothesis $\left[H_{0}^{4}\right]$ was that "there is no significant relationship between the cost and the quality of the MBA. "This hypothesis was subjected to bivariate correlation test and the results revealed that there was a positive significant relationship between the cost and the quality of the MBA $[\mathrm{r}(100)=.432, \mathrm{p}<0.01]$. The same hypothesis was put to a simple linear regression test so as to find out the actual contribution of cost to the quality of the MBA. The results of the ANOVA of the regression showed that there a linear relationship between cost and quality $[\mathrm{F}(1,98)=22.511, \mathrm{p}<0.01]$. This implied that the more of one variable the more of the other. Secondly, the model summary of the regression produced an $\mathrm{Adj} . \mathrm{R}^{2}$ of .178 which translated into $18 \%$ contribution of costs to the quality of the MBA.

Table 6 contribution of cost to the quality of the MBA

\begin{tabular}{|c|c|c|c|c|c|}
\hline \multirow{2}{*}{ Model } & \multicolumn{2}{|c|}{$\begin{array}{c}\text { Unstandardised } \\
\text { Coefficients }\end{array}$} & $\begin{array}{c}\text { Standardized Coef- } \\
\text { ficients }\end{array}$ & Sig \\
\cline { 2 - 4 } & $\mathrm{B}$ & Std. Error & Beta & & \\
\hline 1 (Constant) & 1.182 & .881 & .432 & 1.341 & .183 \\
MB A cost & 1.273 & .268 & & 4.745 & .000 \\
\hline
\end{tabular}

\section{a. Dependent Variable: Quality of the MBA}

In Table 7 , it is seen that the costs had a moderate positive significant contribution to the quality of the MBA $($ Beta $=.432, \mathrm{p}<0.01)$. In view of the above results it can be asserted that null hypothesis [ $H_{0}^{4}$ ], "there is no significant relationship between the cost and the quality of the MBA," was not supported, but instead the alternate one [ $H_{A}^{4}$, "there is a significant relationship between the cost and the quality of the MBA," was supported. Given the high costs of MBA, at least in Ugandan context, 76\% of the respondents stated that all those who join the MBA do not finish their programmes when they should. It can therefore be concluded that even though cost has positive contribution to the quality of the MBA, there are many Ugandan students who find the cost of the MBA prohibitive.

\section{Explanation of hypothesised model of cost and quality}

The model figure 2 takes into account all hypotheses tested in this study. These were three on cost and quality, cost and academic work, and academic and quality of the MBA. Although hypothesis 1 is shown in the figure 2, it is only intended to show the logic of sources of cost, but it is not part of the path diagram. So it not part of the model.

Figure 2 hypothetical model on effect of cost on quality of MBA 


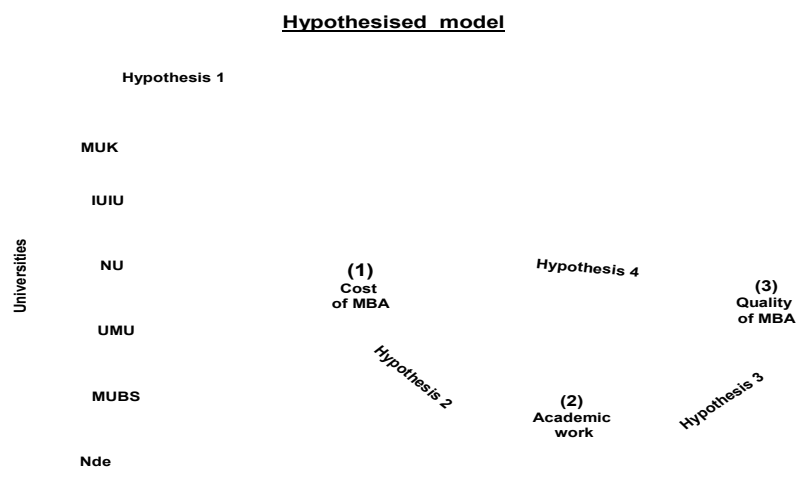

26 The hypothesised model was used in order to establish a more reliable explanation that the quality of an MBA was a function of cost, that is, $q=f(c)$.

In the explanation the following issues are taken into account:

(a) Determining the variables - In the above model, there is an independent variable (cost), and intermediary academic (work), and the dependent (quality). Universities constitute an exogenous units showing where MBA cost emanates from. Universities are not part of the causal paths, for that reason their differences in cost was tested using ANOVA and Gabriel post hoc tests. The paths between a university and cost are not directional hence being recursive.

(b) Establish the causal paths - The causal paths relevant to variable (3) which is quality of MBA are paths from (1) to (2) to (3); and from (1) to (3).

(c) Stating assumptions - (i) all relations are linear, that is, the casual assumptions (what causes what) are shown in the path diagram; (ii) the variables are measured on interval scale.

So the paths in the model have to establish the following relationships:

(1) a positive significant relationship between cost and quality of the MBA

(2) a positive significant relationship between cost and MBA academic work

(3) a positive significant relationship between academic work and quality.

The results were as follows:

\section{Figure 3 paths for hypothesised empirical model}


Hypothesised model

1 cost of
MBA $\quad \begin{gathered}3 \\ \text { Quality of } \\ \text { MBA }\end{gathered}$

A path coefficient indicates the direct effect of a variable as shown below:

$\begin{array}{llc}\underline{\text { Paths }} & \text { Variable } & \text { Path coefficients } \\ \text { P31 }= & \text { Cost and quality } & .43 \\ \text { P21 } & \text { Cost and academic work } & .44 \\ \text { P32 }= & \text { Academic work and quality } & .57\end{array}$

Variable 1 (cost) is the only exogenous variable because it has no arrows pointing to it. So there are two endogenous variables in the model, that is, variable 2 (academic work) and variable 3 (quality of the MBA). Each of these two is explained by one and two variables. In the model academic work which is an endogenous variable is a cause of another endogenous variable, quality.

\section{Effect of decomposition}

The path coefficients were used to decompose correlations in the model into direct and indirect effects corresponding to direct and indirect paths reflected in the arrow of the model. This is based on a rule that in a linear system the total causal effect of variable A on variable B is the sum of the values of all the paths from A to B. Considering that "quality of the MBA" is the dependent variable, and "cost" is the independent variable, the indirect effects are calculated by multiplying the paths coefficients for each path from cost to quality of the MBA:

Cost $->$ academic work $->$ quality of the MBA $=.44 \times .57=.25$

So, .25 is the total indirect effect of cost on quality of the MBA, plus the direct effect .43 . The causal effect of cost on quality of the MBA is $[.25+.43]=.68$.

In the light of the above model, it is appropriate to infer that cost is the major determinant of the quality of an MBA programme. Other factors which account for the remaining .38 should be only peripheral in decision making process about the quality of the MBA.

\section{Conclusion}

The findings in the preceding paragraphs have revealed several things: (i) there is a significant variation in the cost of the MBA programmes at the six universities that participated in this study. When the six universities were rated, it emerged that the Islamic University in Uganda was the most preferred on the account of the cost only of the 
MBA, [31\%]. The least favourable university as far as cost is concerned was Uganda Martyrs University (7\%), that is, UMU was considered the most expensive of all the Universities. Other indications were that for popularity of the MBA, it was the MUBS MBA that was ranked highest [78\%]. Regarding quality of teaching, the Nkumba MBA was ranked the highest [64\%]. All this seems to indicate that there is no single university whose MBA ranks highest on all parameters.

\section{Recommendation}

Since it has been established that cost is a key determinant of the quality of the MBA programmes, appropriate costing of the academic programmes should be carried out by all the universities. Furthermore, given the fact that cost is sometimes a constraint to academic work of poor MBA students, it is suggested that government should create an educational fund from which MBA students constrained by financial hardships can borrow some money and be able to complete their MBAs and then pay back later with some minimal interest. It is only government which can make available loans to students who do not have security.

\section{References}

A brief guide to quality assurance in UK higher education, by the Quality Assurance Agency for Higher Education. (2005 http://www.qaa.ac.uk/public/heguide/

Arbaugh J B (2000a) Virtual classroom characteristics and student satisfaction with internet based MBA courses. In Journal of Management Education. Volume 24. Number 32. available at http://jme.sagepub.com.

Arbaugh J B (2000b) Virtual classroom versus physical classroom; An exploratory study of class discussion patterns and student learning in an asynchronous internet -based MBA course. In Journal of Management Education. Volume 24. Number 213. available at http:// jme.sagepub.com

Arbaugh J B (2000c) An exploratory study of the effects of gender on student learning and class participation in an internet -based MBA course. In Management Learning. Volume 31. Number 503. available at http://mlq.sagepub.com

Appleton, S (2001) "Education, Incomes and Poverty in Uganda in the 1990s". CREDIT Research paper No 01/22. University of Nottingham. www.nottingham.ac.uk/economics/ research/credit.

Bickerstaffe (2004) The cost of the MBA. Available at http://www.bnet.com

Buller P F, McEvoy G M and Cragun J R (1995) A model for developing student skills and assessing MBA programme outcomes through outdoor training. In Journal of Management Education. Volume 19. Number 35. available at http://jme.sagepub.com

Blair, R D D (1998) "Financing Higher Education in Africa". In Higher Education in Africa: Achievements, Challenges and Prospects. Dakar: UNESCO.

Brown R B (2000) Contemplating the emotional component of learning; the emotions and feelings involved when undertaking an MBA. In Management Learning Volume 31. Number 275. Available at http://mlq.sagepub.com

Castleberry S B (2007) Prison field trips: can white-collar criminals positively affect the ethical and legal behaviour of marketing and MBA students? In Journal of Marketing Edu- 
cation. Available at http://jmd.sagepub.com

Cohen A R and Miaoulis G (1978) MBA student anxiety and overreactions: learning from linking the required $\mathrm{Ob}$ and marketing courses. In Journal of Management Education. Volume 3. Number 11. available at http://jme.sagepub.com

Court D (1999) Financing Higher Education in Africa: Makerere, the quiet revolution. Available at http://www.worldbank.org/afr/findings/

Dacko S G (2001) Narrowing skill development gaps in marketing and MBA programmes: the role of innovative technologies for distance learning. In Journal of Marketing Education. Volume 23. Number 228. Available at http://jmd.sagepub.com

Deconinck J and Steiner T (1999) Developing an integrated finance and marketing MBA core course. In Journal of Marketing Education. Available at http://jmd.sagepub.com

Duncan W J (1986) Focussing on the MBA purpose rather than the MBA end. In Journal of Management Education. Volume 10. Number 71. available at http://jme.sagepub.com

Elkin G (1991) Decision-making processes for admitting students to executive MBA programmes. In Management Learning Volume 22 Number 134. Available at http://mlq. sagepub.com

Epelu-Opio, J (2002) Higher Education Reform at System and Institutional Level: the Case of Makerere University.

Fox S (2008) That miracle of familiar organisational things: social and moral order in the MBA classroom. In Organisational Studies. Volume 29. Number 733. Available at http:// oss.sagepub.com.

Financing Universities: Who Pays to Study? (2004) in The Economist January $24^{\text {th }} 30^{\text {th }} \mathrm{pp}$ $23-26$.

Gabriel Y (2005) MBA abd the education of leaders: the new playing fields of Eton. In Leadership. Volume 1. Number 147. Available at http://lea.sagepub.com.

Golen S, Lynch D, Smeltzer L, Lord W J, Penrose J M and Waltman J (1989) An empirically tested communication skills core module of MBA students with implications for the AACSB. . In Journal of Management Education. Volume 13. Number 45. available at http://jme.sagepub.com

Hansen R S (2009) The Master of Business Administration: Is the MBA Worth the Time, Effort, and Cost? http://www.quintcareers.com/MBA

Harris J, Clarke K, Sims D, Morgan E and Nicholls N (1992) MBA courses: learning from diversity and similarity. In Management Learning Volume 23. Number 333. available at http://mlq.sagepub.com

Hay A and Nodgkinson M (2008) More success than meets the eye a challenge to critiques of the MBA: possibilities for critical management education? In Management Learning. Volume 39, Number 21.available at http://mlq.sagepub.com

Hayward, F M (2004) "Making the Case for Higher Education Support”. Kampala: National Council for Higher Education (NCHE). 
Isabella L A (2005) Using existing teams to teach about teams: how an MBA course in managing teams helps students and the programme. In Journal of Management Education. Volume 29. Number 427. Available at http://jme.sagepub.com

James G (2008) Five truths about the MBA. Available at http://www.bnet.com

James G (2008) The secret guide to the MBA classroom. Available at http://www.bnet. com

Kaiza D (2001) The Revolution in Ugandan Universities. In the East African http://nationaudio.com/news/EastAfrican/

Kajubi, W S (2001) "Coping with challenges of higher education in the twenty first century". In Mande W M (ed) Effective Teaching in Higher Education. Entebbe: Nkumba University.

Kleiman L S and Kass D (2007) Giving the MBA programmes the third degree. In Journal of Management Education. Volume 31. Number 81. available at http://jme.sagepub. com.

Legge K, Sullivan-Taylor B and Wilson D (2007) Management Learning and the corporate MBA: situated or individual? In Management Learning Volume 38. Number 440. available at http://mlq.sagepub.com

Mamdani M (2007) Scholars in the marketplace: the dilemmas of neo-liberal reform at Makerere University (1989 - 2005), Kampala: Fountain Publishers.

Mattis M (2008) CBS scores Olympic MBA Keeth Smart. Available at http://blogs.bnet. $\mathrm{com} / \mathrm{mba}$

Maxwell P (1986) MBAs in the distance mode. In Management Learning. Volume 17. Number 226. available at http://mlg.sagepub.com.

Mayanja, M K (2002) Graduate Employment: Investing in the Service Mandate of the African University. Kampala: Makerere University.

Miller J (2007) Choosing the right MBA school. Available at http://blogs.bnet.com/mba

Miller J (2008) Don't make this rookie MBA student mistake. Available at http:// blogs.bnet.com $/ \mathrm{mba}$

Miller J (2009) Three reasons to ban guest speakers from the MBA classroom. Available at http://blogs.bnet.com/mba

Miller N J, Besser T and Malshe A (2007) Strategic networking among small businesses in small US communities. In International Small Business Journal. Available at thttp://isb. sagepub.com

Nath R (1975) The Management training laboratory: an experiential orientation to the MBA programme. In Journal of Management Education. Volume 1. Number 10. available at http://jme.sagepub.com.

Naude P, Band D Stray S and Wegner T (1997) An international comparison of management use of quantitative techniques and the implications for the MBA teaching. In Management Learning. Volume 17.Number 226. available at $\quad \underline{\mathrm{http}: / / \mathrm{mlg} \text {.sagepub. }}$ com.

Noll S (2002) Private institutions need government input. In new vision. 


\section{laffrica.com}

Pay or Decay (2004) in The Economist January $24^{\text {th }}-30^{\text {th }}$. London: The economist Newspaper Limited. Also at http://www.economist.com/print

Plovnick M S and Burke W W (1979) Perspectives on teaching OD in an MBA programme. In Journal of Management Education. Volume 3. Number 8. Available at http:// jme.sagepub.com

Roscoe J T (1975) The fundamental research statistics for the behavioural sciences. $2^{\text {nd }}$ edition. Holt, Rinehart and Winston: New York.

Sanyal, B C and Martin, M (1998) Managing Higher Education with Special Reference to Financial Management in African Universities". In Higher Education in Africa: Achievements, Challenges and Prospects. Dakar: UNESCO.

Simpson R, Sturges J, Woods A and Altman Y (2005) Gender, age, and the MBA: An analysis of extrinsic and intrinsic career benefits. In Journal of Management Education. Volume 29. Number 218. Available at http://jme.sagepub.com

Sims D, Morgan E, Nicholls J, Clarke K and Harris J (1994) Between experience and knowledge: Learning within the MBA programme. In Management Learning. Volume 25, Number 275. available at http://mlq.sagepub.com

Sinclair A (1995) Sex and the MBA. In Organisation. Volume 2. Number 295. Available at http://org.sagepub.com

Sinclair A (1997) the MBA through women's eyes; learning and pedagogy in management education. In Management Learning Volume 28. Number 313. available at http:// mlq.sagepub.com

Smith L J (2001) Content and delivery: a comparison and contrast and electronic and traditional MBA marketing planning courses. In Journal of Management Education. Volume 23. Number 35. available at http://jme.sagepub.com.

Thomas A B (1984) the value of MBAs? The fitting role of Business schools. In Management Learning. Volume 15, Number 201. available at http://mlq.sagepub.com

Thompson E R (2002) Chinese perspectives on the important aspects of an MBA teacher. In Journal of Management Education. Volume 26. Number 229. available at http://jme. sagepub.com.

Thursfield D (2008) Managers' learning in a UK local authority: the political context of an in-house MBA. In Management Learning. Volume 39, Number 295. available at http://mlq. sagepub.com

Tonn J C, and Milledge V (2002) Team building in an MBA "gateway" course: lessons learned. In Journal of Management Education. Volume 26. Number 415. available at http:// jme.sagepub.com.

Viljoen J, Holt D and Petzalt S (1990) The MBA experience: participants' entry level conception of management. In Management Learning. Volume 39, Number 295. available at http://mlq.sagepub.com

Wavamunno G B K (2000) Gordon B K Wavamunno: the story of an African entrepreneur. Kampala: Wavah Books Limited. 
Wright, E H (1998) "Financing Higher Education and Partnership with Production and Service Sectors". In Higher Education in Africa: Achievements,

Challenges and Prospects. Dakar: UNESCO. 